1494

\title{
疲労き裂発生・進展に基づく確率論的寿命分布評価に関する研究*
}

\author{
中井啓 晶*1, 倉 敷 哲 生*2, 座 古

\section{Evaluation on Distribution of Fatigue Life with Crack Initiation and Propagation Based on Probability Theory}

勝*2

\author{
Hiroaki NAKAI, Tetsusei KURASHIKI and Masaru ZAKO*3 \\ ${ }^{* 3}$ Department of Materials and Manufacturing Science, Osaka University, \\ 2-1 Yamadaoka, Suita-shi, Osaka, 565-0871 Japan
}

\begin{abstract}
It is very important for the damage tolerance design of a structure to reveal the behavior of fatigue cracks of the used material. They have some uncertainties, the random applied loads or the residual strength caused by manufacturing process and so on. It is difficult to evaluate the behaviors of real fatigue cracks. In this paper, an evaluation method for fatigue life based on fatigue crack length has been proposed. Fokker-Planck equation, which can describe fatigue crack propagation under random load and random propagation resistance, has been proposed. The distribution of fatigue life has been analyzed by combining both of the distribution of crack initiation life and the distribution of propagation life.
\end{abstract}

Key Words : Fatigue, Probabilistic Method, Crack Propagation, Crack Initiation, Markov Process, Fokker-Planck Equation, Failure Probability

\section{1. 緒言}

航空機器, 発電プラント部品等における損傷許容 設計では応力解析に加えて，効果的な点検間隔の設定 之補修を行うために, 疲労き裂に関する種々の性質の 把握が最重要課題である. しかし，損傷許容設計の実 用化を考える際，き裂発生・進展過程には，作用する 荷重の不規則性や，残留強度等の材料の不均質性など, さまざまな不確定要素が伴うため, 疲労き裂発生・進 展の的確な評価は困難であるのが現状である.

そこで, そのようなばらつきによる不確定性を伴 う疲労現象を確率論的に取り扱う研究が行われている. 疲労寿命を疲労き裂発生寿命と疲労き裂進展寿命に分 けて考えると，き裂発生寿命に関しては幾つかの解析 的モデル化が行われているが，未だその決定的な解明 には至っていない，例えば，井原らは繰り返し応力が 負荷されるごとに材料に蓄えられる累積エネルギーが 限界值を超えたときに, 結晶粒寸法程度の疲労き裂が

* 原稿受付 2005 年 2 月 9 日.

${ }^{* 1}$ 大阪大学大学院工学研究科 (\$ 565-0871 吹田市山田丘 2-1).

*2 正員, 大阪大学大学院工学研究科(画 565-0871 吹田市山田 丘 2-1).

E-mail : zako@mit.eng.osaka-u.ac.jp
発生するという確率モデルを提案している(1). 一方, き裂進展寿命に関しては, 確率微分方程式を用いた解 析が行われている(2).き裂進展過程は, 部材に加わる 外力の不規則性，部材の材質の不均質性，内包するき 裂の数量, 寸法, 形状等の不確定性の影響を受ける. そこで, 疲労き裂の進展過程を, き裂長さや残留強度 のような材料の特性值の確率分布が時間の経過につれ て変化卞る確率過程と考える. そして, き裂の安定成 長で成り立つ Paris 則に基づき, 材料強度のばらつき 及び不規則荷重を考虑して疲労き裂進展過程を記述し た確率微分方程式を用いたき裂長解析が行なわれてい る. 鶴井, 石川らは疲労き裂進展過程をマルコフ過程 として確率微分方程式でのモデル化を行っているき. しかし，それも初期き裂寸法がある確率分布特性を有 する場合の残存寿命を評価することに留まり, 疲労寿 命の推定までには至っていない.

本研究では材料・構造物の疲労寿命推定法を確立 することを目的に，疲労試験により得たき裂発生寿命 の分布特性評価，不確定性要因を伴う疲労き裂進展に ついて確率論を用いてモデル化を行い，き裂発生・進 展寿命の各分布を考慮し，このモデルに基づく疲労寿 
命の評価手法構築の研究を行ったのでその結果につい て報告する.

\section{2、ルコフ過程を用いたき裂進展モデル}

21 き裂進展モデル

疲労の安定き裂成長段階（疲労き裂進展の IIb 段

階）で成り立つ Paris 則を基に，無次元化を施すと式

(1) を得る.

$$
\begin{aligned}
\frac{d x}{d n} & =\varepsilon\left(\frac{\Delta \sigma}{\Delta \sigma_{0}} \sqrt{x} \cdot F(x)\right)^{m} \\
& =\varepsilon \cdot Z^{2(\lambda+1)} \cdot x^{\lambda+1} \cdot\left\{F\left(l_{0} x\right)\right\}^{2(\lambda+1)}
\end{aligned}
$$

ここで, $x=\|_{0}$ は $n$ 回の応力繰返し後のき裂長さ $l$ を初 期き裂長さ $b$ で無次元化したもので, $\triangle \sigma$ は応力振幅, $F(x)$ は応力拡大係数における形状等に関係する項を無 次元化した関数である. また, $Z=\Delta \sigma / \Delta \sigma_{0}$ は無次元化 応力振幅, $\varepsilon, m$ は材料定数であり, 便宜上 $l=m / 2-1$ と している. 上述したように, き裂の進展過程は外力の 不規則性や材料強度の不均質性の影響を受ける. そこ で, 外力の不規則性については時々刻々と不規則に変 動する応力振幅 $Z_{m}$ 材料強度の不均質性などの内因 については不規則進展抵抗 $C_{n}$ として定義すると, 式 （1）は次のようになる.

$\frac{d x}{d n}=\varepsilon \cdot C_{n} \cdot Z_{n}^{2(\lambda+1)} \cdot x^{\lambda+1} \cdot\left\{F\left(l_{0} x\right)\right\}^{2(\lambda+1)}$

この式は，き裂の進展とともに不規則に変動する $C_{n}$, $Z_{n}$ を含むため, 通常の微分方程式のように初期值 $x(0)$ が与えられても，方程式を積分して解を求めることは 不可能である. しかし, き裂進展の不確定挙動を記述 する確率微分方程式では, 解そのものを求めるよりも 平均値や分散といった解の確率的性質を知ることが重 要となる. ここでは, 確率過程 $x$ が Markov 過程であ ると仮定し, 1 次の確率密度関数と推移確率密度関数 として表現する.

\section{Markov 過程}

Markov 性を仮定すれば, 確率分布関数および密度 関数は最後の時間における条件にのみ依存する. そし て, 初期長さ $x_{i}$ のき裂が, $n$ 回の応力繰返しの後にき 裂長さ $x$ 以下である確率分布関数を $W\left(x, n \mid x_{i}\right)$, その密 度関数を $w\left(x, n \mid x_{i}\right)$ とすれば, 次の Fokker-Pland 方程式 が得られる(2)。

$$
\begin{aligned}
\frac{\partial w\left(x, n \mid x_{i}\right)}{\partial n}=-A(n) & \frac{\partial}{\partial x}\left\{g(x) \cdot w\left(x, n \mid x_{i}\right)\right\} \\
- & \frac{1}{2} B(n) \frac{\partial}{\partial x}\left\{\frac{d g(x)}{d x} g(x) \cdot w\left(x, n \mid x_{i}\right)\right\} \\
& +\frac{1}{2} B(n) \frac{\partial^{2}}{\partial x^{2}}\left\{g^{2}(x) \cdot w\left(x, n \mid x_{i}\right)\right\}
\end{aligned}
$$

ここで, $A(n), B(n)$ は $C_{n}, Z_{n}$ に依存する項で, それぞ れ次式で表される.

$$
\begin{aligned}
& A(n)=\varepsilon \cdot E\left[C_{n} \cdot Z_{n}^{2(\lambda+1)}\right] \\
& \begin{aligned}
B(n)=2 \varepsilon^{2} \int_{-\infty}^{0} & \left\{E\left[C_{n} \cdot Z_{n}^{2(\lambda+1)} C_{n+n^{\prime}} \cdot Z_{n+n^{2}}^{2(\lambda+1)}\right]\right. \\
& \left.\quad-E\left[C_{n} \cdot Z_{n}^{2(\lambda+1)}\right] \cdot E\left[C_{n+n^{\prime}} \cdot Z_{n+n^{\prime}}^{2(\lambda+1)}\right]\right\} d n
\end{aligned}
\end{aligned}
$$

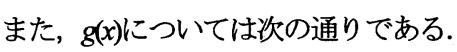

$$
g(x)=x^{\lambda+1} \cdot\left\{F\left(l_{0} x\right)\right\}^{2(\lambda+1)}
$$

この式 (3) の方程式を解き, その解の密度関数 $w(x$, $\left.n \mid x_{i}\right)$ は次式で表される.

$$
\begin{aligned}
w\left(x, n \mid x_{i}\right) & =\frac{1}{g(x) \sqrt{2 \pi \int_{0}^{n} B\left(n^{\prime}\right) d n^{\prime}}} \\
& \times \exp \left\{-\frac{\left\{\int_{x_{i}}^{x} \frac{d x^{\prime}}{g\left(x^{\prime}\right)}-\int_{0}^{n} A\left(n^{\prime}\right) d n^{\prime}\right\}^{2}}{2 \int_{0}^{n} B\left(n^{\prime}\right) d n^{\prime}}\right\}
\end{aligned}
$$

この式を基に, 初期き裂長さが確定值の場合と分布を 有する場合の解を示す. なお, 本論文中では, 負荷応 力振幅の不規則性 $Z_{n}$ を一定 $\left(Z_{0}\right)$ とし，また形状に関 する補正項 $F(x)$ による影響は無いものとして議論を行 う. 上述の条件および $E\left[C_{n}\right]$ が 1 となるように定数 $\varepsilon$ を設定できることから，式（4）の $A(n)$ は次のように 表される.

$$
A(n)=\varepsilon \cdot Z_{0}^{2(\lambda+1)}
$$

\section{1 初期き裂長さが確定値の場合}

式 (7) の積分形は,

$W\left(x, \tau \mid x_{i}\right)=\Phi\left[\frac{x_{i}^{-\lambda}-x^{-\lambda}-\lambda \tau}{\lambda \sqrt{\frac{\alpha}{2 \lambda+1}\left\{x_{i}^{-(2 \lambda+1)}-\left(\operatorname{Max}\left[0, x_{i}^{-\lambda}-\lambda \tau\right]\right)^{\frac{2 \lambda+1}{\lambda}}\right.}}\right]$

ただし 
$\tau=\varepsilon \cdot Z_{0}^{2(\lambda+1)} n$

$\alpha=\frac{\xi_{0}\left\{E\left[C_{n}^{2}\right]-\left(E\left[C_{n}\right]\right)^{2}\right\}}{\left(E\left[C_{n}\right]\right)^{2}}$

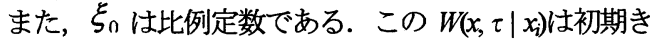
裂長さ $x_{i}$ が応力繰返し数 $n$ の後にそのき裂長さが $x$ 以 下である確率を意味する.この式を用いて行ったき裂 長さ分布の推移解析例を図 1 に示す. 図中，縦軸は 確率密度を示し，横軸にき裂長さ $x_{c}$ を取っている. この時, 各值は $\varepsilon=2.5 \times 10^{-6}, \quad \lambda=0.5, \quad \alpha=2.2 \times 10^{2}$ とし た.この結果より, 応力繰返しに伴いき裂長さ分布の 平均値，分散は共に増大していることがわかる.

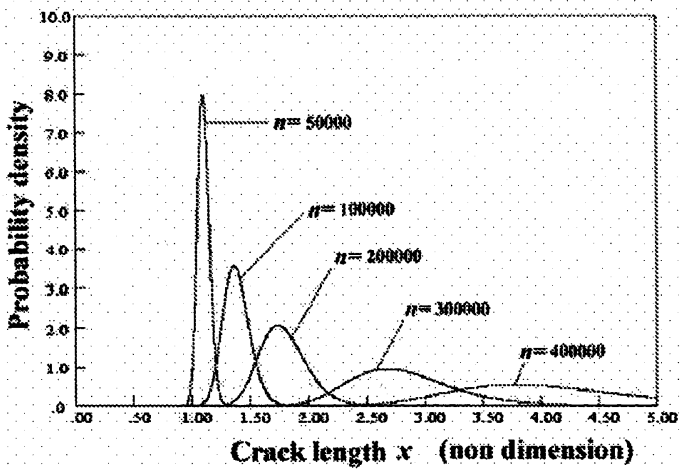

Fig.1 The distribution of fatigue crack length with fixed initial crack length

\subsection{2 初期き裂長さがワイブル分布の場合}

初期き裂長さが形状母数 $\beta$, 尺度母数 $x_{0}$ ，位置 母数 $\gamma$ のワイブル分布に従う場合, 式 (7) の積分形 は,

$$
\begin{aligned}
W\left(x, \tau \mid \beta, x_{0}, \gamma\right)=\int_{0}^{\infty} W\left(x, \tau \mid x_{i}\right) d G\left(x_{i}\right) \\
=\int_{0}^{\infty} \Phi\left[\frac{x_{i}^{-\lambda}-x^{-\lambda}-\lambda \tau}{\left.\lambda \sqrt{\frac{\alpha}{2 \lambda+1}\left\{x_{i}^{-(2 \lambda+1)}-\left(\operatorname{Max}\left[0, x_{i}^{-\lambda}-\lambda \tau\right]\right)^{\frac{2 \lambda+1}{\lambda}}\right.}\right]}\right. \\
\times \frac{\beta}{x_{0}\left(\frac{x_{i}-\gamma}{x_{0}}\right)^{\beta-1} \exp \left\{-\left(\frac{x_{i}-\gamma}{x_{0}}\right)^{\beta}\right\} d x_{i}}
\end{aligned}
$$

$\tau ， \alpha$ につては，式 (10)，（11）と同様である. 初期き裂長さが $\beta=10.0, \quad x_{0}=1.0, \quad \gamma=0.0$ のワイブル 分布に従うとした場合のき裂長さの推移評価例を図 2 に示す.き裂准展パラメータの值は図 1 と同様である. 結果は, 図 1 に示した初期き裂長さが確定值の場合
と同様の傾向を示したが，両図の同繰返し数における き裂長さを比較すると, 繰返し数が増加しても両図の ばらつきの差は明確であり，初期におけるき裂長さの ばらつきがき裂進展後，つまりは疲労寿命分布にも大 きく影響することが確認できた。

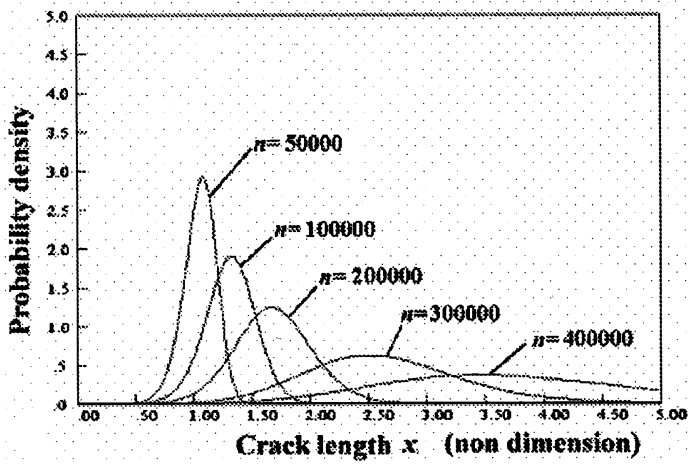

Fig.2 The distribution of fatigue crack length with weibull distribution of initial crack length

\section{3.き裂発生寿命を考慮した疲労寿命評価}

\section{1 裂発生寿命分布の推定}

疲労き裂発生は，材料の種類やその結晶に大きく 左右される. また, 同じ材料でも, 試験片が平滑材の 場合は特に，き裂発生寿命は長くなり，そのばらつき も大きなものとなる. よって, 疲労き裂発生寿命を, その結晶学的, 力学的観点から解析することは困難で ある. そこで, 疲労き裂発生寿命を, 実験的に求め, そのばらつきを確率的に評価する事が重要となる. 疲 労き裂の発生を厳密に決定することは困難であるため, 通常, あるき裂長さに達したときの応力繰返し数をも ってき裂発生寿命と定義される. したがって，実際に は定義されたき裂長さに達するまでのき裂進展寿命を 含んだ寿命となる. 本研究においても，き裂長さがあ る長さに達した時の応力繰り返し数をき裂発生寿命と 定義する. ここでは，それが 3 母数ワイブル分布に従 うとして，ばらつき評価，分布推定を試みる.

分布の母数推定法については, モーメント法や最 尤法などがあるが，簡便で最もよく用いられている方 法は, 確率紙を用いる方法である.ここでは特に, 確 率紙に目視で直線を引く代わりに計算で直線を当ては める. この場合, 2 母数ワイブル分布の形状母数 $\alpha$, 尺度母数 $\beta$ の推定值 $\hat{\alpha}, \hat{\beta}$ については, 次式で計算さ れる(3). 
$\hat{\alpha}=\frac{\sum Y^{2}-\left(\sum Y\right)^{2} / n}{\sum X Y-\sum X \sum Y / n}$

$\hat{\beta}=\exp \left(\frac{\sum X}{n}-\frac{\sum Y}{n \hat{\alpha}}\right)$

ここで, $\mathrm{X}, \mathrm{Y}$ は次式で表される.

$X=\ln (x-\gamma)$

$Y=\ln \{-\ln (1-F)\}$

上式を 3 母数ワイブル分布に適用する場合, 位置 母数 $\gamma$ を直接推定することはできないため, 最尤法や 最小二乗法, 相関係数法などが用いられる. 酒井らは これらの母数推定に関して，モンテカルロ法を用いた 推定精度の検証を行い，ワイブル確率紙を用いた母数 推定では相関係数法が最も適切であると報告している (4), (5).

また, 疲労試験では打ち切りデータを含む場合が 少なくないが, このような場合の取り扱いとして, Johnson の方法や Nelson の方法を用いて順位数のあて はめが必要である. 本手法では, 少数の試験本数を対 象としていることから，サンプルサイズの小さい場合 にも使える Johnson法を用いる.

\section{2 疲労寿命分布の推定}

疲労寿命 $n_{f}$ は一般に, き裂発生寿命 $n_{i}$ とき裂進展 寿命 $n_{p}$ の和として表される. 本研究においても, 疲 労現象をき裂発生過程とき裂進展過程に分けて取り扱 うものとする.

き裂発生寿命とき裂進展寿命, それぞれの確率密 度関数を $f(n), f_{p}(n)$ とし，それぞれの過程が互いに独 立であるとすると, 疲労寿命の確率密度関数 $f(n)$ は次 式で表される.

$$
f\left(n_{f}\right)=\frac{\int_{0}^{n_{f}} A \cdot d n_{i}}{\int_{0}^{\infty}\left(\int_{0}^{n} A \cdot d n_{i}\right) d n}
$$

ここで，Aは次式で表される関数である

$$
A=\int_{n_{i}}^{n_{i}+d n_{i}} f_{i}\left(n_{i}\right) \cdot d n_{i} \cdot \int_{n_{i}}^{n_{i}+d n_{i}} f_{p}\left(n_{f}-n_{i}\right) d n_{i}
$$

上式は畳み込み積分の一種であるため, 数式的に解 を得ることは困難であるので, 数值積分により解を 求める. その際の手順は以下に示す通りである.

(1)き裂発生寿命 $n_{i}$ を固定し, $f_{(}\left(n_{i}\right), f_{p}\left(n_{f}-n_{i}\right)$ を求める.
(2) $f\left(n_{i}\right), f_{p}\left(n_{f}-n_{i}\right)$ それぞれに $\Delta n_{i}$ を乗じ，その発生確率 の積 $P_{i}=\left\{f_{i}\left(n_{i}\right) \cdot \Delta n_{i}\right\} \cdot\left\{f_{p}\left(n_{j}-n_{i}\right) \cdot \Delta n_{i}\right\}$ を計算する.

(3) $n_{i}$ を $\left[0, n_{\mathrm{f}}\right]$ で変化させて(1)，(2)の計算を行い，P(n) = $\Sigma P_{i}$ を求める.

(4) $n_{f}$ を十分に大きな範囲で次々と変化させ, $P(n)$ の分 布を得る.

(5) $P(n)$ を全体が 1 となる様に正規化し，疲労寿命の確 率密度分布 $f\left(n_{f}\right)=P\left(n_{j}\right) / \int P(n) \mathrm{d} n$ を決定する.

この手順においてき裂発生寿命分布 $f_{(}(n)$, き裂進展寿 命分布 $f_{f}(n)$ はそれぞれ 3.1 節および式 (9) により推 定した密度関数である.

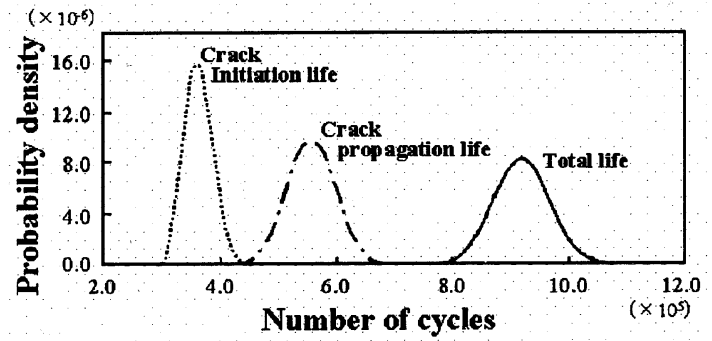

Fig.3 The distribution of fatigue life considering the distributions of initiation life and propagation life

図 3はここで述べた手法を用いて疲労寿命解析を行 った例である.き裂発生寿命分布として, 形状母数 $\beta$, 尺度母数 $x_{0}$, 位置母数 $\gamma$ がそれぞれ, $2.83,7.11$ $\times 10^{4}, 3.00 \times 10^{5}$ のワイブル分布を想定し，き裂進展 解析では, 2.2 .1 項と同様の条件で, 初期き裂長さ $x_{i}=$ 1.0 , 限界き裂長さ $x=10.0$ として計算した.

この例では, き裂発生寿命, き裂進展寿命が共に $10^{5}$ オーダーの分布を想定しており, その結果求まっ た疲労寿命分布は，双方の分布のばらつきを反映した 分布形状となっている.

市川らは既に，き裂の発生とその伝ぱを分離した 疲労寿命の検討を行っているが(の，本研究では，き裂 進展寿命分布を解祈的に求めており，任意のき裂長さ に対する寿命評価が可能であり，さらに後に述べる S-N 線図へと展開しているところに特徵がある.また, 市川らは疲労寿命分布の計算手法としてモンテカルロ シュミレーションを用いているが, 本研究では, 数值 積分を行うことによって, より実験結果に基づいた解 を計算しているものと考える.

\section{3 実試験データーの適用例}

次に，提案手法の実試験データへの適用を考える. 図 4 は市川らが行った A2024-T3 アルミニウム合金試 
験片の疲労試験結果のを基に，疲労寿命分布を推定し た結果である．まず，き裂発生寿命データからそれが 3 母数ワイブル分布であるとし, その值を同定すると, 図4に示すように $\beta=2.83, x_{0}=2.11 \times 10^{4}, \gamma=0.00$ と なった.

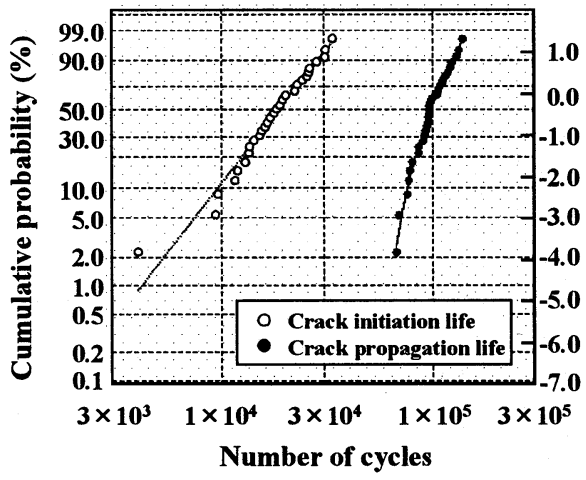

Fig 4 The distribution of crack initiation and propagation life (weibull probability paper)

また，き裂進展寿命データからき裂進展に関する各 パラメータの值を $\varepsilon=2.5 \times 10^{6}, \lambda=0.5, \quad \alpha=2.2 \times 10^{2}$, 無次元限界き裂長さ $x=20.0$ とした. ここから提案手 法により疲労寿命を推定すると, その分布は図 5 に示 した通りとなり，実験による疲労寿命データから直接 推定した分布とほぼ一致することが確認できた.

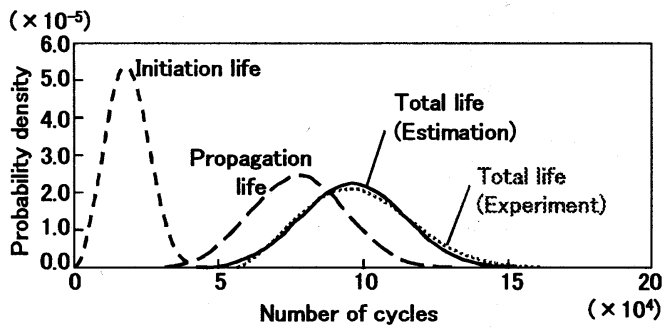

Fig.5Example of application of the proposed method

\section{4.き裂長さに基づく S-N 線図}

\section{1 作成手順}

疲労寿命の評価は S-N 線図により行われ, 応力振 幅レベルと繰返し数の関係のみが示される. しかし， 損傷許容設計の重要性が高まる一方で, その設計法が 十分に確立されていないのが現状である. それは，S$\mathrm{N}$ 線図が寿命と繰返し数という関係のみを表し，損傷 度に関する情報を有していないためであると考える。 そこで, 先に行った疲労寿命評価を用いて, き裂長さ
を考慮した S-N線図を提案し，その作成法について述 べる.

手順は以下の通りである.

(1)疲労試験を実施し, 同一応力振幅レベルのき裂発生 寿命を試験片 3 本以上， 2 応力振幅レベル以上で観 測.

(2)さらに同試験中のき裂進展結果からき裂准展パラメ 一夕を決定.

(3)各応力振幅レベルのき裂発生寿命を確率分布関数で モデル化.

(4)応力振幅レベル間でのき裂発生限界線を内挿.

(5)き裂准展寿命解析を実施.

(6)き裂発生寿命とき裂進展寿命の各分布から疲労寿命 推定.

まず，疲労き裂の観察を目的とした疲労試験を実 施する. き裂発生と定義するき裂長さや，観察するき 裂長さは試験片寸法等により異なるが，き裂の観察方 法としては，レプリカを用いた方法や試験片に発生す るき裂を直接顕微鏡で観察する方法がある. 観察によ り, き裂発生寿命とその後進展していくき裂の長さと 進展速度を記録する.この試験を同一応力振幅レベル において最低でも 3 本の試験片を用いて行い，それを 異なる応力振幅レベルでも実施する. そして, 試験結 果からき裂進展パラメータを決定する.

次に, 各応力振幅レベルでのき裂発生寿命を 3 母 数ワイブル分布としてモデル化し，その分布パラメー 夕を求める. これを, 疲労試験を行ったそれぞれの応 力振幅レベルで行う. 応力振幅レベル間の寿命につい ては，S-N 線図の傾斜部が，一般に片対数または両対 数で直線となることから，安全側を考慮して次式を用 いて, 平均寿命 $N_{i}$ で内挿寸る.

$$
N_{i}=c \Delta \sigma^{-b}
$$

ここで, $b, c$ は定数である. さらに, 疲労試験によ り決定したき裂進展パラメータを用いて, 所望の忘力 振幅レベルにおけるき裂進展解析を実施し, き裂進展 寿命分布を推定する.

このようにして求まったき裂発生寿命, き裂進展 寿命が互いに独立であると仮定し，それぞれの分布か ら疲労寿命分布を計算する。

\section{2 提案手法による疲労寿命評価}

本手法を適用した場合に得られる S-N 線図の模式 図を図 6 に示す.ここでは, き裂発生寿命分布と疲 労寿命のみを分布として示しているが，き裂発生後の 寿命はばらつきを考慮して任意のき裂長さに対して解 
析的に求めることができるため, き裂長さ $l=l_{i}$ に対す る寿命も確率分布として評価可能である.

従来の S-N 線図との違いは，き裂長さに基づき寿 命を評価しているため, き裂長さ毎の寿命を決定でき， さらに, 疲労寿命を確率的に取り扱うことで, ばらつ きを破壊確率として考慮できる点である.これは，実 用性の面において重要となり,これまで繰返し数のみ で行われていた疲労設計を, き裂長さという確認可能 な数值で設計可能であり，損傷許容設計を行う上で損 傷度の基準となる. また, 提案手法では検査等により 現在のき裂長さが明らかとなると, それを基準に疲労 寿命を再計算し, 修正可能である. これにより, 常に 最新情報を活用した残存寿命予測が行えることとなる.

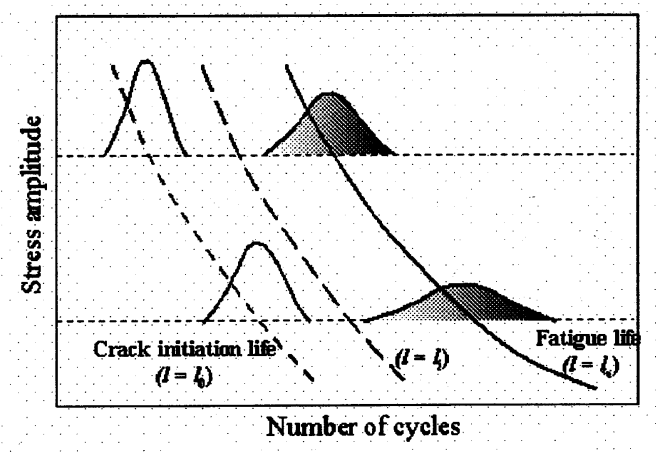

Fig.6Scheme of S-N diagram considering crack length

\section{5. 粕言}

重要性が高まる損傷許容設計のための疲労設計基 準構筑を目的として, き裂長さに基づく寿命評価手法 の提案を行った.

き裂長さを確率変数としてき裂進展に関する確率 微分方程式を解き，その解を Folker-Plandk 方程式とし て得た.これにより, 初期き裂長さが確定值または分 布を有する場合におけるき裂進展寿命分布が評価可能 となった. き裂発生寿命に関しては, 疲労き裂がある 長さに達する寿命をき裂発生寿命として定義し, 疲労 試験におけるき裂観察から発生寿命分布を推定する. その分布については，これまでの統計的結果から 3 母 数ワイブル分布がよく一致しており, そのパラメータ 決定法について述べた.
また，一般に疲労寿命がき裂発生寿命とき裂進展 寿命の和で表されることから，それらが互いに独立で あると仮定して, 各分布の和から疲労寿命を数值積分 により計算できることを示した. 解析例として行った 計算では, き裂発生分布にき裂進展寿命のばらつきが 作用し, 疲労寿命分布はさらに分散の大きな分布とな っており，実験による疲労寿命分布ともよく一致して いた.

最後に，従来の S-N 線図に代わる設計基準として， き裂長さに基づく S-N線図を提案し，その作成手順に ついて述べた. 提案手法では, 疲労過程をき裂長さと 対応付け，またばらつきを確率分布として取り扱うた め, 点検・検查等による情報から残存寿命を評価した り, 破壊確率としてばらつきを定量的評価できるなど の利点を有している. また, 最新の情報から寿命予測 の修正ができ，取得した情報を十分に活用して高い精 度の寿命評価が行える.

\section{文献}

(1) C.Ihara, ATsurui, Fatigue of Metals as Stochastic Phenomena, Trans. of ASME. J. Eng. Mate. Tech., 99 (1977) , 26.

（2）石川 浩, 鶴井 明, 進展抵抗の不規則性を考 虑した疲労き裂進展過程の確率モデル，日本機 械学会論文集 (A 編)，50, 1309, (1983).

（3）日本材料学会編，機械・構造技術者のための実 用信頼性工学, 養賢堂, (1987).

（4）田中道七, 酒井達雄, 3 母数ワイブル分布の母 数推定について, 材料, 28, 609, (1989).

（5）酒井達雄, 田中道七，3 母数ワイブル分布の母 数推定について（続報），材料， 29，638， (1990).

（6）市川昌弘, 田倉隆行, 田中 栄, き裂の発生と 伝ぱを分離した疲労寿命の信頼性工学的研究, 材料, 31, 697, (1982). 